\title{
Public Spending on Childcare as an Indicator of Gender Sensitivity of Budget
}

\author{
Ana Marija Sikirić \\ University of Rijeka, Faculty of Economics, Croatia \\ sikiric@efri.hr \\ Josip Čičak \\ University of Rijeka, Faculty of Economics, Croatia \\ josip.cicak@efri.hr
}

\section{ABSTRACT}

\begin{abstract}
Nowadays, women make more than $60 \%$ university graduates, but their status in the labour market does not fully reflect educational achievements, which leads to greater financial dependence of women on men and gender inequality in other areas. To determine the potential solutions to this situation the paper analyses correlation between public spending on childcare services, gender equality in terms of time spent in unpaid work and differences in employment rates of women with children under the age of 6 and women without children in EU. Results confirm significant positive correlation between specified variables and highlight the need to take into account different gender roles of men and women in the decision-making during the budgeting process in order to ensure equal opportunities to male and female labour force in the labour market as a precondition for greater gender equality.
\end{abstract}

Keywords: gender equality, gender-sensitive budgeting, childcare

JEL: H52, I24, J12

\section{Introduction}

In spite of legislation and the perception of individuals, gender inequality in European society is still powerful and best-reflected in the position of women in the labour market. Nowadays, women make more than a half of the population, and more than $60 \%$ of university graduates, but their contribution to appraised economic activities, growth and prosperity is far below their potential. Although women are an enormous human resource, their status in the labour market does not fully reflect educational achievements. In the labour market, gender inequality is still present, and it is reflected in lower 
activity of female labour force, lower employment rates, and lower incomes of women in comparison with men'.

Exclusion from the labour market results in women who are financially dependent on men, which creates a hierarchical subordination between equally valuable social groups and deepens the problem of gender inequality. Only by employment do women achieve financial independence which gives them control over their own lives and the possibility of choice. Greater financial independence will improve the position of women in other areas; therefore, more intense involvement of women in the labour market is the basic precondition for greater gender equality in society.

In order to understand the problem of the unequal position of women in the labour market, it is necessary to make a clear distinction between the concepts of sex and gender. Basically, the word sex is used in relation to mankind, for all distinctive features that are biologically and inherently conditioned. On the other hand, gender indicates a common social and cultural concept of sex in human society, i.e. implies culturally and socially produced images, perceptions, expectations, norms, conventions, attitudes, values, behaviours, and emotions that society ascribes to biological sexes, i.e. men and women (Galić, 2009).

The problem of gender inequality in the labour market occurs because of disregard of gender differences that result from different roles the society assigns to men and women. According to the GEI (Gender Equality Index), which is a measure of gender equality in the EU, the greatest inequality between women and men was reported in terms of time, which implies time spent in unpaid work ${ }^{2}$ and leisure ${ }^{3}$. Women do much more unpaid work, and most women are still disproportionately burdened with housework and childcare. This is the result of socially shaped roles of men and women according to which women take care of the household and raise children, while men support the entire family. Such a division of roles results in unequal distribution of unpaid work between women and men, which puts women at disadvantage in relation to paid work and can be considered one of the main causes of inequality in the labour market.

1 In 2014, the average activity rate of women aged 15-64 in all 28 EU Member States was by 11,6 percentage points lower then the activity rate of male labour force. The average employment rate of women aged 15-64 in 2014 was by 11 percentage points lower than the employment rate of men (Eurostat LFS). In 28 EU Member States in 2013, women's incomes were lower, on average, by 15 percentage points than men's incomes, i.e. women earn only $85 \%$ of the incomes of men (Eurostat).

2 Unpaid work implies all production activities that take place outside of the labour market, which an individual performs as part of household work; for example, housework, care for children, the elderly and disabled, volunteer work, transportation services, major and minor repairs, working in the family business, etc. These activities are considered production activities because they try to meet human needs with limited resources, and are classified as unpaid work, because the individual performs them independently, regardless of the fact that, in theory, they can be done by purchasing services and products on the market (Swiebel, 1999).

3 More at: http://eige.europa.eu/ 
The paper does not question whether the existing roles and responsibilities of men and women are right or not; the focus of the paper is on examining and proving with solid arguments that disregard of the existing gender differences results in gender inequality, and that it is necessary to take into account different roles of men and women in order to solve this problem, and to provide them with equal opportunities in the labour market despite their differences. Therefore, greater emphasis has recently been placed on measures that will enable women to reconcile work and family life, and thus provide them more intense involvement in the labour market, which is a precondition for greater equality in other areas.

\section{Gender-Sensitive Budgeting}

The problem of gender inequality is increasingly discussed in economic research papers due to realisation that gender equality is a critical component of social progress and that it has a wide and clear impact on economic and social development. The results of various studies have proven that greater gender equality has the following economic effects: an increase in human capital $^{4}$, increase in competitiveness ${ }^{5}$, increase in savings ${ }^{6}$, reduction of corruption ${ }^{7}$, greater macroeconomic stability ${ }^{8}$, and reduction of the risk of poverty?.

By making macroeconomic decisions, the government can increase losses in the society which are the result of inequality between men and women. To avoid this, it is necessary to take into account the existing inequalities and

4 Human capital is defined as knowledge, experience, abilities, creative skills, and innovativeness that make the labour force productive. Increasing human capital from the quantitative aspect implies an increase in the number of workers, while the qualitative aspect implies knowledge, skills and innovativeness of individuals. Greater equality in education results in more educated, and therefore more effective, female labour force (Murphy, 2009).

5 By providing equal opportunities to men and women in the labour market, companies will be able to hire the most productive workers, which will result in higher output and greater competitiveness of the company (Ward, Lee, Baptist, \& Jackson, 2010). Besides, more productive labour force ensures a higher return on investment and thus attracts investments. Increase in investments directly increases economic growth. This effect is relatively small, but statistically significant (Klasen \& Lamanna, 2009).

6 A study conducted in 20 mid-industrialised countries showed that an increase in the employment rate of women and women's incomes has a positive effect on savings. Savings are diverted into investments through the financial sector. Savings of the population are an important source of capital, especially in countries that have limited access to foreign capital markets. It is also important to note that the impact of greater gender equality on savings also depends on the movements of interest rates, taxation, the propensity to save through credit cooperatives, national culture, etc. (Seguino \& Floro, 2003).

7 Increase in the proportion of women in the Parliament by 25 percentage points increases the Corruption Index by 1 point. The Corruption Index ranges from 0 - the maximum level of corruption to 6 - the lowest level of corruption (Swamy, Knack, Young, \& Azfar, 2001).

8 A research conducted in Switzerland proved the thesis that greater participation of women in decision-making results in a reduction of budget deficit in local budgets. This is attributed to longer life expectancy of women and their awareness of the negative consequences of a great deficit on future generations, which indirectly has a positive effect on macroeconomic stability (Krogstrup \& Wälti, 2007).

9 A higher level of women's education increases the possibility of getting a better-paid job and thus significantly reduces the risk of poverty (Ward et al., 2010). 
differences between men and women in the decision-making process, and to implement decisions that contribute to gender equality.

Contemporary macroeconomic policy is a combination of measures in several segments of economic policy: monetary policy, balance of payments, income, prices, and fiscal policy. Given that the issue of gender inequality can be closely connected with inadequate redistribution of resources and opportunities and inequality in meeting the needs of men and women, fiscal policy is considered an excellent tool for achieving gender equality, particularly the budget as its most important instrument.

The state budget is the main instrument for financing public expenditure in a country. Budget usually refers to a plan of public revenues and expenditures for a specific time period, usually one year. However, the budget is much more than that; it is not only economic, but also political, social and developmental instrument. Its structure on the revenue and the expenditure side clearly shows how the national government sets its priorities and how it forms and intends to implement its policies and decisions (Wehner \& Byanyima, 2004). The budget, as the basic financial planning act of a country, is also one of the most important instruments for implementation and enforcement of the planned government decisions and can also be used for achieving the objective of gender equality.

The government and citizens see the budget as a gender-neutral instrument, because total public revenues and expenditure, which result in budget surplus or deficit, are shown numerically (Budlender \& Sharp, 1998). None of the budget classifications imply participation according to gender (Sikirić \& Vašiček, 2013). However, due to different socially and naturally shaped roles of women and men, their needs are different, and therefore, decisions made in the budgeting process have a very different impact on men and women; thus on gender equality. By making budgeting decisions i.e. using the method of collecting public revenues through various tax measures and decisions on the structure of public spending, the government could further deepen or reduce existing social inequalities between women and men.

Since the government is obligated to promote equality among citizens, redistribute resources from those who have to those who have not, and equally meet the needs of all citizens, there has been a growing need in the past 20 years for the government and other authorities, before they make any decisions on collection and spending of public money, to consider, among other things, what effects their decision will have on women and men. The budget that attempts to eliminate the existing gender inequality is in theory called gender-sensitive budget, i.e. gender budget (Sikirić \& Vašiček, 2013).

Budlender and Sharp (1998) define gender-sensitive budget as a budget analysis that determines different impacts of the budget on women and men. 
The Council of Europe defines gender budget as implementation of the gender awareness policy ${ }^{10}$ in the overall budgeting process where the implementation of gender awareness policy is reflected through a gender evaluation of budget effects, inclusion of a gender perspective in all phases of the budget cycle, and modification of public revenues and expenditures in order to promote gender equality (COE, 2005).

Schratzenstaller (2008) highlights the dual focus of gender budgeting. The first focus is on analysing the impact of public revenues and expenditures on gender equality. Based on the results of the analysis, the focus is then placed on the modification of the budget structure in such a way that public revenues and expenditures contribute to greater gender equality.

According to Klatzer and Stiegler (2011), gender budget is the application of financial and budgetary cycle, i.e. public revenues and expenditures, in order to achieve the goals of gender awareness policy.

The Ministry of Women and Child Development in India defines gender budget as a budget in which gender-conditioned patterns of behaviour of men and women in the society are recognised, and public funds are allocated for the implementation of policies and programmes that will lead to changes in these patterns of behaviour so that they could contribute more to genderequal society (Government of India, 2007).

Several main features of gender-sensitive budget are pointed out from the above definitions:

- Gender-sensitive budget takes into account different social roles of men and women in society,

- Gender-sensitive budget implies the analysis of the entire budgeting process from a gender perspective, which determines the effects of public revenues and expenditures on male and female population,

- Gender-sensitive budget implies a modification of public revenues and expenditures so that they contribute to greater gender equality in society,

- Gender-sensitive budget directs the collection of public revenues and public spending to achieve the objectives of gender awareness policy, i.e. greater gender equality.

Overall definition of gender-sensitive budget can be derived from the above features:

Gender-sensitive budget, taking into account different socially shaped roles and needs of men and women, is a process of continuous analyses of spending and methods of collecting budget revenues from the perspective of gender equality at all levels of the budgeting process, and their modification

10 Gender-awareness policy implies reorganisation, improvement, development, and evaluation of political processes, so that gender equality is included as an objective in all policies at all levels and at all stages (COE, 2005). 
with the goal to achieve greater gender equality in society. The starting point is the assumption that the budget does not only affect distribution of material and financial resources, but also of non-material resources, especially time. The basic objective is to implement such a budget that will not only have a different impact on women and men, but will also promote gender equality as one of the important economic, political and social objectives.

Gender budgeting is often misunderstood as a 'feminist initiative'or a budget that puts women in a privileged position. It should be clear that gender budgeting does not imply a separate budget for women, but that it rather, unlike the usual budget, recognises and takes into account unpaid work in the household as well as care for the family and the community in addition to paid work (Elson, 2002). Unpaid work covers a range of different activities, but this paper highlights the activities relating to childcare and education. The reason is that the impact of overall unpaid work can hardly be precisely measured and determined, while the impact of parenthood is expressed more clearly and concretely by monitoring specific economic and social phenomena. One of them, for example, is the ratio of the level of employment of women with children and women without children. Thus, in the EU Member States in 2014, the average employment rate of women aged 20-49 with one child under the age of 6 was $89,6 \%$ of the employment rate of women without children, the employment rate of women with two children under the age of 6 was 84,5\%, and the employment rate of women with three or more children under the age of 6 was $62,4 \%$ of the employment rate of women without children (Eurostat LFS).

Motherhood increases the amount of women's unpaid work and therefore has a negative impact on womens' employment rates, which ultimately results in lower employment rates and lower incomes of women in relation to men. Women are at greater risk of unemployment, have more difficulties in keeping the job and it is harder for them to return to the labour market after the absence. In other words, women's exclusion from employment caused by motherhood reduces work experience, human capital, makes it more difficult to return to employment and retain managerial positions, and in case of more children, the atrophy of human capital becomes more acute. Employment breaks also reduce economic independence and future social security of retired women (Fultz \& Stenhilber, 2004; according to Matković, 2008). In contrast, fatherhood has a positive impact on men's employment rates. Employment rates of men with children are considerably higher (by about 8 percentage points) than employment rates of men without children, which is undoubtedly a consequence of socially formed roles and responsibilities of men and women (Mills et al., 2014).

Gender-sensitive budget tends to meet the different needs of men and women to achieve greater gender equality. Greater gender equality is possible if women are financially independent, i.e. employed, and they will be employed if they are able to harmonise their professional obligations 
with family. Therefore, in order to meet the needs of women, it is necessary to finance the budget measures which will allow reconciliation of work and family life. One way is the financing of childcare; the government can use its budget to facilitate reconciliation of work and family life. By providing a sufficient number of places in public institutions of childcare and subsidising the costs of services of childcare, women are 'liberated' from all-day childcare, which enables full employment, i.e. working full-time. The goal is to provide women, if they so wish, with the possibility to return to their workplaces and work full-time. Therefore, the provision of adequate childcare service may be one of the key elements of a gender-sensitive budget.

Availability of childcare services has been recognised by scientists and public policy makers as a very important precondition for the employment of women, especially those with children younger than 6. Increasing public spending on childcare is also associated with an increase in full-time employment of women (OECD, 2012). Besides, the availability of childcare services enables family planning, so the countries that have done the most in terms of childcare presently have the highest employment rates, but also the highest fertility rates (EC, 2013a).

\section{Literature Review}

Overview of scarce scientific literature has not produced any studies covering the topic of gender-sensitive budget or the effects of financing the function of early childhood education. However, a number of empirical and theoretical research, independent of the concept of gender-sensitive budget, indicates the positive impact of availability of childcare on women's employment, i.e. implicitly on improvement of the position of women in the labour market. Thus, the impact of availability of public services of childcare on the reduction of the extent of unpaid work of women and women's employment is very relevant for the research in the context of achieving greater gender equality in the labour market, and thus indicators of establishment of a gendersensitive budget.

Previous studies of gender-sensitive budgeting and the impact of childcare on women's employment are presented below.

\subsection{Literature Review on Gender-Sensitive Budgeting}

Gender-sensitive budgeting is a new, interdisciplinary, and underexplored area that emerged as a reflection of a modern, high level of democracy development and human rights in the broadest sense. The complexity of the effects of implementation of gender budgeting refers to many fields of social sciences. They can be identified and studied in terms of economics, public finance, sociology, political science, demography. Only a few researchers have covered gender-sensitive budgeting, and among them, especially important are Debbie Budlender, Diane Elson and Rhonda Sharp, whose research 
and works greatly contributed to the development of the idea and concept of gender-sensitive budgeting. They participated in the launch of initiatives for introducing gender-sensitive budget, identification of preconditions for its introduction, participants in the process, as well as problems that slow down the process.

The first initiatives related to gender-sensitive budgeting emerged in 1984 in Australia (COE, 2005). The example of Australia served as the basis for launching initiatives in other countries, primarily in the United Kingdom in 1989, Canada in 1995, and South Africa in 1996. In Europe, the UK's gendersensitive budget initiative remained isolated until the end of the 1990s, when France started following their ideas, and other countries followed (COE, 2005). Nowadays, gender equality is one of the main priorities of the EU, but instead of creating a separate policy for the promotion of gender equality, the European Commission decided in 1996 to incorporate gender equality in all policies and activities (Galizzi, 2010). In 2001, under the presidency of Belgium, the European Union set the year 2015 as the ultimate deadline for the Member States to implement gender-sensitive budgeting (IPU, 2004) ${ }^{11}$.

From 1984 to 2011, over 40 countries around the world started 'experimenting' with the gender budget (Nallari \& Griffith, 2011). However, Hofbauer (2003) suggests that there is still lack of progress in achieving greater gender equality, because priority is constantly given to economic objectives, and in the macroeconomic decision-making, one does not take into account the different needs, roles and responsibilities of men and women. Elson (1999) points out that this is the most obvious disregard of unpaid work in the decision-making process, which places women in a disadvantaged position in comparison with men in terms of paid work.

In recent years, the subjects covering gender-sensitive budget in scientific literature were almost exclusively covered by implementation guidelines and various reports on the steps taken so far, the experiences of different countries, the recorded problems or shortcomings which slowed down the process (Budlender, 2009; COE, 2005; Government of India, 2007; Nordic Council of Ministers, 2006; Prenner, 2007; Ratsan, 2008; UN Women, 2012). Most of the published works are descriptive, narrative or prescriptive. Only a few references are analytical, but they also fail to provide any concrete evidence of the results of gender-sensitive budgeting research. Previous studies have only provided recommendations and emphasised the necessity

11 In some European countries, gender-sensitive budgeting is built into core legislation. An example of such a country is Austria, which was the first country that has built gender budgeting into its constitution in 2009, and made it legally binding for all administrative bodies in the public sector (Klatzer, 2010). In other countries, gender-awareness policy is included in government activities and has a strong influence on the decision-making process during the budgeting cycle and the implementation of other policies. In some countries, ongoing initiatives related to the introduction of gender-sensitive budgeting are usually in the form of a pilot-project as a way of testing the ground, while some countries have committed to the introduction of gender budgeting, but the process has not started yet, and priority was given to solving of some other problems (Elson \& Sharp, 2010). 
and potential positive effects of gender-sensitive budgeting. The studies have mainly focused on the analysis of public spending from the perspective of gender, in particular spending related to education and health care, under the assumption that these are the sectors that mostly cover the so-called 'female issues (Combaz, 2013).

\subsection{Literature Review on Childcare and Female Employment}

The impact of childcare on women's employment has two dimensions: price and availability. Researchers from the USA, Canada, and the United Kingdom focused in their research on the relationship between the price of childcare services and women's employment (Anderson \& Levin, 1999; Baker, Gruber, \& Milligan, 2005; Connelly, 1992; Powell, 1997; Viitanen, 2005). Assuming that an increase in prices of childcare services reduces the effective salary of women, different scientific methods were used to estimate sensitivity of women's employment to the change in costs of childcare services. The obtained results proved that an increase in prices of childcare services reduces the likelihood of women's employment, greater sensitivity to price changes was recorded in countries where the availability of childcare services is not limited, while sensitivity to price changes is barely noticeable in areas where childcare services are limited, or their working hours do not correspond to full-time working hours (Gustaffson \& Stafford, 1992).

In the EU Member States, childcare services are mainly public and both the price and the availability of the service are very important factors (Kreynfeld \& Hank, 1999). Availability has two dimensions: the working hours and the number of vacancies in relation to the number of children in a particular area. If an area does not have a sufficient number of places in preschool institutions, then the price has almost no influence on the decision on employment and the use of childcare service (Del Boca \& Vuri, 2006). Even if there is a sufficient number of places, working hours are often not adapted to full-time work (at least 9 hours, because travelling to work should also be counted in), nor are the working hours flexible, which results in the fact that, although parents have the option of using the service of childcare, this does not offer the possibility of full-time employment (Kreynefeld \& Hank, 1999; Wrochlich, 2004).

In addition to childcare, some authors included maternity leave and maternity compensations in the model (Spansenoska \& Fethu-Vehapi, 2011; Gornick, Meyers, \& Ross, 1996, 1998; Misra, Budig, \& Boeckmann, 2011; De Henau, Meulders, \& O'Dorchai, 2010; Mikucka, 2008). Maternity leaves allow mothers to spend more time outside of the labour market; by contrast, adequate childcare services allow mothers to spend more time in the labour market; in other words, they enable reconciliation of family life with full-time work of both parents and thus have a direct positive impact on women's employment.

Although the relationship between availability, cost, demand for childcare services and the supply of female labour force is very complex and diverse, 
previous empirical studies have confirmed the theoretical hypotheses that adequate childcare services increase the likelihood of women's employment. In this paper impact of childcare services on women's employment will be linked for the first time with gender sensitive budgeting by analysing correlation between public spending on childcare and gender equality in terms time spent on unpaid work as a precondition for higher employment of women with children younger than six years.

\section{Data and Methodology}

Nowadays, all the EU Member States have established a system of formal childcare. However, its organisation and financing considerably varies from country to country. Many countries consider childcare a necessary public function and allocate significant public funds for its financing. Increased allocations make the service of childcare financially more accessible to citizens. Thus, in some countries, children can use the childcare services practically for free from the earliest childhood, while in some countries, provision of the services of childcare is left to the private sector, and parents are expected to cover the costs. High costs of childcare services reduce the likelihood of their use as well as the effective income of women, which has the same effect as a reduction of income, i.e. reduces the likelihood of employment and the number of working hours. Lowering the cost of childcare services increases the likelihood of women's employment (Connelly, 1992; Anderson \& Levin, 1999; Del Boca \& Vuri, 2006).

Since relative commitment of a government to a certain area is shown by the share of expenses allocated for a specific purpose in GDP, Figure 1 presents the share of public spending on childcare services in GDP for individual EU Member States for which data were available. Based on these data, it will be clarified which countries recognise the service of childcare as an important factor of parents' return to the labour market. 
Figure 1: Total public spending on childcare - as \% of GDP, 2012

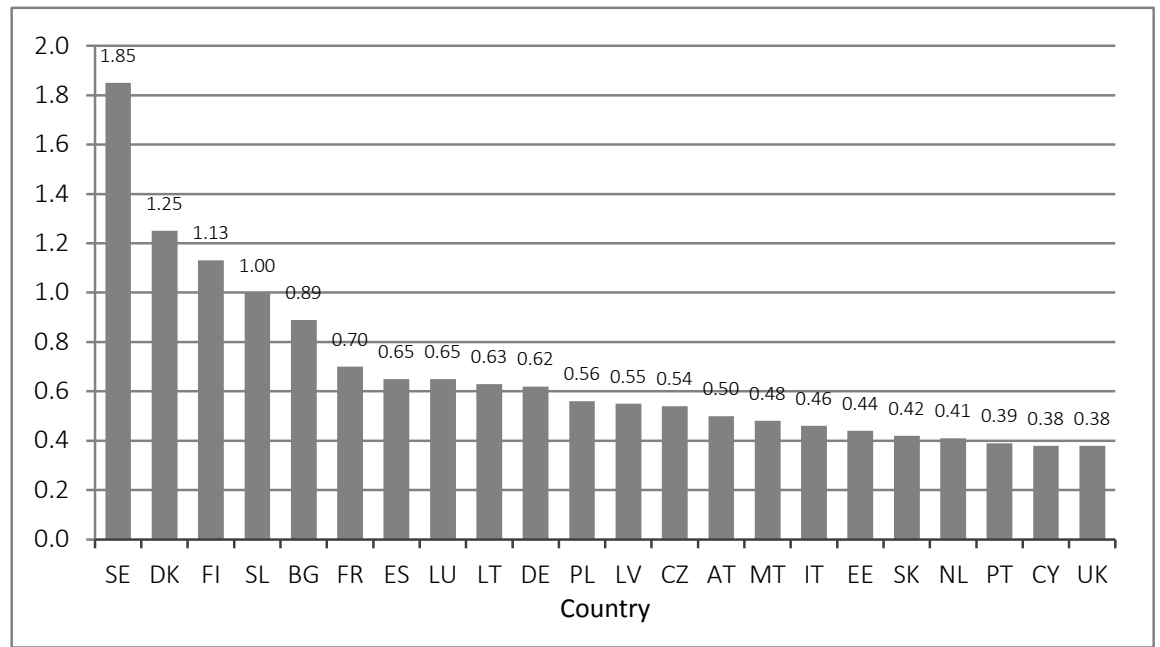

Source: Eurostat, European Union Statistics on Education, [educ_uoe_fine06]

Available data on public spending on childcare as a percentage of GDP were found in the database of Eurostat for only 22 countries. The available data show that the greatest allocation for childcare services is in Sweden, followed by Denmark, Finland, and Slovenia. In these countries, all the childcare institutions are public or subsidised from public funds. Bulgaria and France allocate slightly lower amounts because a part of the service, especially that relating to children less than 3 years of age, is transferred to the private sector and it is expected from parents to cover a share of the costs of these services (EACEA, 2014). Ensuring affordable childcare services in other countries is not high on their list of priorities, or its organisation is largely left to the private sector; this especially relates to Cyprus and the United Kingdom ${ }^{12}$.

Data on the amount of public spending expressed as a percentage of GDP allow for the comparison of different European countries with different economies, monetary currencies and living standards, but basically do not tell much about the adequacy of childcare services in countries. An increase in public spending can make the childcare service financially more accessible; however, although affordability is a very important factor in providing access to childcare for all children, especially those in need, i.e. children who come from families with low income, availability is equally, if not more, important. If in a given area there is an insufficient number of a vacancy in childcare institutions, the price has almost no influence on the decision to use childcare services and choose employment (Del Boca \& Vuri, 2006). Even if there is a sufficient number of vacancies, working hours are often not adapted to full-time work (at least 9 hours), nor are working hours flexible, which results in the fact that, although

12 It should be taken into consideration that in rich economies with high GDP, a relatively small share of expenditures for preschool education in relation to GDP could imply higher investment in absolute terms than a larger share in countries with a lower GDP. 
parents have the option to use the childcare service, it does not give them the possibility of full-time employment (Kreynefeld \& Hank, 1999; Wrochlich, 2004). In this context, the EU set the so-called Barcelona target in Barcelona in 2002. It implied that by 2010, all Member States have to provide childcare to at least $90 \%$ of children between 3 years old and the mandatory school age and at least 33\% of children under 3 years of age (EC, 2013b).

By 2010 , only six ${ }^{13}$ Member States met both criteria. The average inclusion of children less than 3 years of age in childcare services at the EU level was lower than 25\%, and children aged 3 to school age, 84\% (EC, 2013a). In March of 2011, the Member States again committed to reach the Barcelona target in the framework of the European Pact for Gender Equality (2011-2020), because the desired employment rate of $75 \%$ cannot be achieved without increased involvement of women in the labour market, and it can be facilitated by the harmonisation of family and professional obligations.

By 2012, at the level of all Member States, fulfilment of the criterion related to children under the age of 3 was $27 \%$, which is an increase of more than 2 percentage points compared to 2010, while fulfilment of the criterion relating to children older than 3 was $83 \%$, which is a decrease of 1 percentage point compared to 2010.

Of the 28 Member States, only six countries managed to meet both criteria of availability of childcare services: Denmark, Sweden, Belgium, France, Slovenia, and Spain. Except for these six countries, the first criterion relating to the availability of childcare services for children under 3 years of age was fulfilled by three other countries: the Netherlands, Luxembourg, and Portugal, and the second criterion by five more countries: Germany, Italy, Estonia, Malta, and Bulgaria. Countries with the lowest percentages of fulfilment of the criteria are mainly East European countries, especially Poland and the Republic of Croatia. These countries still have a long way to go before they fulfil the criteria set by the Barcelona target.

Whether or not setting of the Barcelona target resulted in greater employment of parents, especially women with children under the age of 6 , is shown on Figure 2 which shows the trend of employment rates of women with children under the age of 6 at the level of EU-28 expressed as a proportion of the employment rate of women without children.

13 Belgium, France, Sweden, Slovenia, Denmark and the United Kingdom. 
Figure 2: Employment rates of women aged 20-49 with one, two, three or more children under the age of 6 expressed as a proportion of the employment rate of women without children at the level of EU-28, 2005-2014

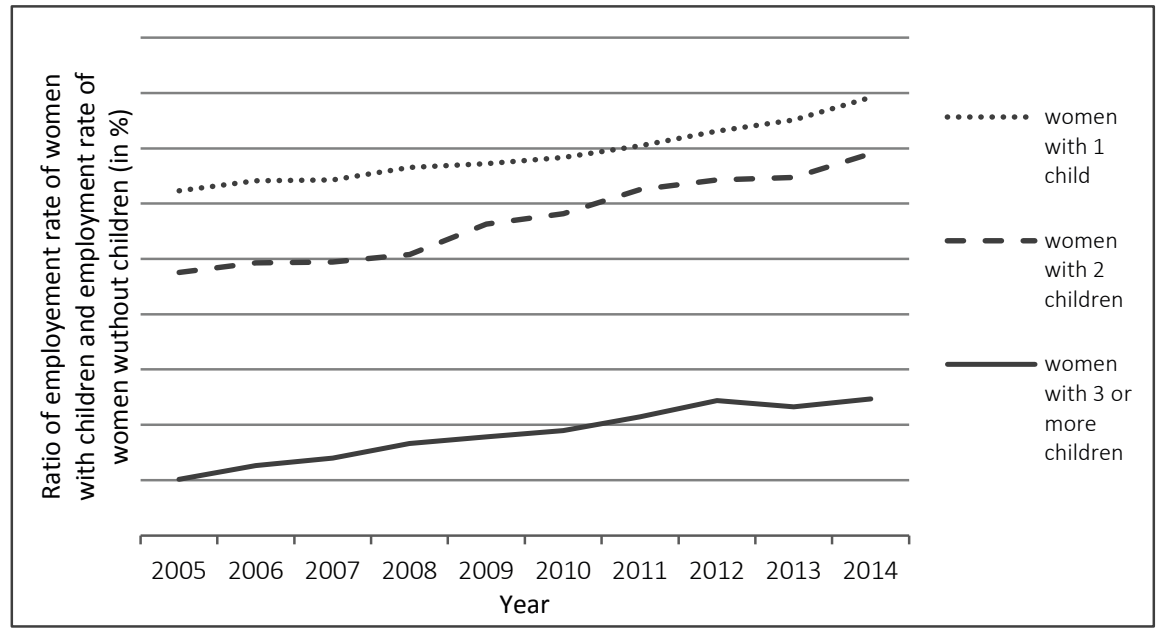

Source: Eurostat, European Union Labour Force Survey (EU-LFS), [lfst_hheredch]

The data on employment rates of women with children under the age of 6 and without children are available from 2005 onwards. However, regardless of the fact that it is impossible to obtain insight into the relationship of employment rates of women with children under the age of 6 and the employment rates of women without children before the introduction of the Barcelona target, Figure 3 shows a growing trend from 2005 to 2014, which indicates that, by gradual fulfilment of the set criteria, the difference between employment rates of women without children and employment rates of women with children under the age of 6 started declining. By expressing the employment rate of women with children under the age of 6 as a share in the employment rate of women without children, the effect of all other factors that have an impact on increasing employment of women with children and without children is nullified. It is therefore assumed that the current growth of the ratio of employment rates of women with one, two, three or more children under the age of 6 and employment rate of women without children is associated with greater availability of childcare services.

The research is based on the hypothesis that childcare services, by reducing the extent of women's unpaid work, contribute to greater gender equality in terms of time spent in unpaid work, which creates a basic precondition for a more intensive involvement of women in the market as the basic precondition for greater gender equality in society. However, it can be assumed that there is also a correlation in the opposite direction, i.e. in the desire to return to the labour market after maternity leave, women aspire to reduce unpaid work, which increases the demand for childcare services, and increased demand also results in greater supply and higher public spending for childcare services (Figure 3). 
Figure 3: Correlation between childcare services with gender equality in terms of time spent in unpaid work and employment of women with children under the age of 6

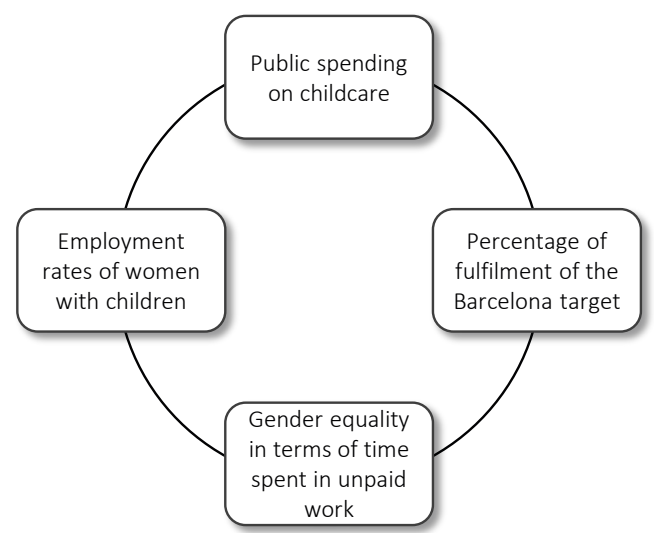

Source: created by the author

The direction of relationship between childcare services and employment of women with children cannot be easily determined, but possible research hypothesis is that the variables will show a positive linear relationship. Because positive linear relationship is assumed, calculation of Pearson's correlation coefficient will be used to analyse potential statistical correlation level between the following variables:

1. The share of public expenditure for childcare services in GDP (CCPE ${ }^{14}$ ) and the percentage of fulfilment of both criteria of the Barcelona target $\left(\mathrm{BT}^{15}\right)$ for the $22 \mathrm{EU}$ Member States in 2012 to determine whether a larger percentage of fulfilment of the set criteria is linked with the amount of public spending for childcare services;

2. Percentage of fulfilment of both criteria of the Barcelona target (BT) and gender equality in terms of time spent in unpaid work (TGE ${ }^{16}$ ) measured by the GEI index for EU-28 in 2012 in order to establish whether greater gender equality in terms of time spent in unpaid work is associated with the availability of childcare services;

3. Gender equality in terms of time spent in unpaid work (TGE) measured by the GEI index, and the relationship between the employment rate of women aged 20-49 with one (ER1) or two (ER2) or three and more children $\left(E R 3^{17}\right.$ ) under the age of 6 , and the employment rate of women aged 20-49 without children for EU-28 in 2012 to determine whether employment of women with children under the age of 6 is associated with gender equality in terms of time spent in unpaid work.

\footnotetext{
14 Source: European Union Statistics on Education, [educ_uoe_fine06]

15 Source: European Union Statistics on Income and Living Conditions (EU-SILC), [ilc_caindformal] 16 Source: European Institute for Gender Equality, Gender equality index in 2012, available at http://eige.europa.eu/gender-statistics/gender-equality-index

17 Source: European Union Labour Force Survey (EU-LFS), [lfst_hheredch]
} 


\section{Results and Discussion}

In order to establish the correlation between childcare services, gender equality in terms of time spent in unpaid work and differences in employment rates of women with children under the age of 6 and women without children, the calculated correlation coefficients are presented in Table 1. The purpose is to examine whether increased public spending for childcare services and greater availability of childcare services by reducing the extent of unpaid work of women increases gender equality in terms of time spent in unpaid work and employment of women with children under the age of 6 , and vice versa.

Table 1: The correlation coefficients between variables

\begin{tabular}{|l|c|c|}
\hline Variables & CCPE & TGE \\
\hline BT & $0.528^{*}$ & $0.720^{* *}$ \\
& $(0.012)$ & $(0.000)$ \\
\hline \multirow{2}{*}{ ER1 } & & $0.556^{* *}$ \\
& & $(0.005)$ \\
\hline ER2 & & $0.481^{*}$ \\
& & $(0.017)$ \\
\hline ER3 & & $0.521^{*}$ \\
& & $(0.011)$ \\
\hline
\end{tabular}

Notes:

** Correlation is significant at the 0.01 level (2-tailed).

* Correlation is significant at the 0.05 level (2-tailed).

Source: Author's Calculations

The correlation coefficient between public spending for childcare services (CCPE) and the percentage of fulfilment of the Barcelona target criteria (BT) is 0.528 (Table 1) and points to mid-level positive correlation, which is statistically significant at the $5 \%$ level of significance. This confirms the hypothesis that greater availability of childcare services is associated with higher public spending for childcare services, and vice versa.

The correlation coefficient of 0.720 in Table 1 between the percentage of fulfilment of Barcelona target criteria (BT) and gender equality in terms of time spent in unpaid work (TCE) indicates a mid-level positive correlation, which is statistically significant at the level of significance of $1 \%$. In other words, greater gender equality in terms of time spent in unpaid work (TCE) is associated with a higher percentage of fulfilment of the criteria set by the Barcelona target (BT), and vice versa. Increased availability of childcare services liberates women from all-day childcare and reduces the extent of unpaid work, resulting in greater equality between men and women in terms of time spent in unpaid work.

Correlation coefficients in Table 1 also confirm the positive correlation between gender equality in terms of time spent in unpaid work and the ratio of employment rate of women with one child (ER1), or two children (ER2), 
or three or more children (ER3), and employment rates of women without children. The increase in the correlation between employment rates of women with children under the age of 6 and women without children indicates that the existing difference between them is reduced. According to correlation coefficients, smaller difference is associated with greater gender equality in terms of time spent in unpaid work, and vice versa. The highest coefficient was recorded in the variable that refers to employment of women with one child under the age of 6 , which is statistically significant at the significance level of $1 \%$, while the two others are slightly lower and are statistically significant at the significance level of $5 \%$.

The obtained correlation coefficients confirm the correlation between the level of public spending for childcare services and their availability. In other words, in order to fulfil the criteria set by the Barcelona target, it is necessary to engage public funds and use them to make childcare services more accessible to more inhabitants and thereby reduce the extent of unpaid work in the household and increase gender equality in terms of time spent in unpaid work. Reducing the extent of unpaid work and greater gender equality in terms of time spent in unpaid work facilitate women's harmonisation of family and professional life and intensifies their return to the labour market. It can certainly have a positive impact on gender equality in the labour market. The greatest correlation of gender equality in terms of time spent in unpaid work and employment of women with children under the age of 6 was recorded with the variable ER1, which refers to the share of the employment rate of women with one child under the age of 6 in the employment rate of women without children, indicating that childcare services largely increase return to the labour market of women with one child, and to a lesser extent, women with two children, assuming that they have more difficulties in reconciling family and professional life, despite childcare services. Three and more children under the age of 6 certainly make balancing professional and family life more difficult, but the correlation variable is slightly higher than in the case of women with two children, which means that an increase in the availability of childcare service increases the employment rate of women with three or more children more than in the case of women with two children. This can be interрreted as follows: if childcare services were not available, a smaller number of women with three or more children would decide to return to the labour market than women with two children; thus, the provision of childcare services increases employment of women with three or more children to a greater extent than of women with two children.

Correlation coefficients confirm a relation of medium intensity; however, since women's employment depends on a number of other factors, it would be unrealistic to expect a higher correlation coefficient. For example, in addition to availability, it is important that the working hours of childcare institutions are adapted to full-time work, preferably to flexible working hours, for parents who work in shifts, because parents often have the option 
of using the service, but for reasons of limited working hours of institutions do not have the possibility of full-time employment (Kreynefeld \& Hank, 1999; Wrochlich, 2004). Besides, Blau and Ferber (1992) point out that, if women were willing to sacrifice unpaid work for paid work, it should primarily be socially acceptable (according to Gornick et al., 1996). Research results indicate that highly educated women care less for stereotypes and it is thus easier for them to decide to work, but it is also a fact that they earn more in the labour market than less educated women, so the opportunity cost of their noninclusion in the labour market is higher (Kreynfeld \& Hank, 1999). Maternity leave and maternity compensations are also important factors. Too little and too much maternity leave has a negative effect on women's employment, because if there is no leave, mothers have to leave the labour market to take care of their child, and if the leave lasts too long, their work continuity diminishes, as well as their salaries and the likelihood of a return to the labour market. Leaves allow mothers to spend more time outside the labour market; by contrast, adequate childcare services allow mothers to spend more time in the labour market. In other words, they enable reconciliation of family life with full-time work of both parents and have a direct positive impact on women's employment (Del Boca \& Vuri, 2006; Spansenoska \& Fethu-Vehapi, 2011; De Henau et al., 2010; Mikucka, 2008). Stier, Lewin-Epstein and Braune (2001) suggest that, in some countries, women's employment rates are high because of the possibility of working part-time. However, Gelo, Strmota and Smolčić (2010) argue that part-time work can be an alternative to termination of employment, but accepting such jobs aggravates the position of women in the labour market in the long run, and should therefore be viewed as a link to full employment in later life.

\section{Conclusions}

Gender inequality and its consequences has become a frequent subject of discussion in the framework of economic research. The fact that women, although they presently make more than a half of university graduates, are still under-represented in the labour market in all EU countries indicates that gender inequality is not just a problem of socially and economically underdeveloped countries, but also of modern societies. The reason for unequal participation of men and women in the labour market can be linked to their socially shaped roles according to which men are providers for the family, and women take care of the children and the household. In other words, society expects of men to participate in the labour market, while women are expected to do most of the unpaid work, which often deprives them of opportunities and places them in a disadvantaged position in the labour market. Exclusion of women from the labour market results in their financial dependence on men, which limits their control over their own lives and results in gender inequality in other areas. 
Due to its functions of allocation and distribution, the budget is considered an excellent tool for achieving the objective of gender equality. Although the budget may seem gender-neutral, assuming that men and women, because of their different roles, also have different public needs and social positions, decisions made in the budgeting process certainly do not have the same impact on male and female population. It is therefore necessary to consider the differences between men and women in the decision-making process and analyse all public revenues and expenditures from the point of view of gender aiming to introduce changes that will contribute to greater gender equality and equal meeting of the needs of men and women.

Since the basic precondition of greater gender equality is financial independence of women, it is necessary to intensify involvement of women in the labour market. Women will be included in the labour market if they are able to harmonise their professional and family obligations. Therefore, a gender-sensitive budget should be used to finance measures and programmes that will facilitate the harmonisation of obligations in terms of unpaid and paid work. One of such measures is childcare service, which liberates parents from all-day childcare and enables them to return to the labour market after maternity leave. By engaging public funds, this service is made available to a large number of the population, which has a positive impact on gender equality in terms of time spent in unpaid work through reduction of unpaid work. Reduction of unpaid household work makes it easier for women to harmonise family and professional life and enables them to return to the labour market and exploit their work potential, if they so wish.

For all of the above reasons, public spending for childcare services could be an important indicator of gender sensitivity of the government and one of the steps towards a gender-sensitive budget. It should be taken into account that the implementation of gender budgeting requires a longer period of time, expressed political will, opening of the budget process to a wider group of participants, setting priorities for equality issues, insisting on recognition of unpaid work and changing the way in which national and local budgets are planned and executed. Introduction of a gender budget should start by raising awareness of the negative consequences of the existing, often unintentional, gender inequality, the impact of government decisions on gender equality, and positive effects of gender budgeting. 
Ana Marija Sikiric,, Mecon, is a Novice Researcher at Faculty of Economics, University of Rijeka. Since 2011 researcher in the project 'Innovation, technology transfer and competitiveness of Croatian exports'. The Project is financed by Ministry of Science, Education and Sports. Author or coauthor of 4 published scientific papers and 3 professional papers. Participant of 5 international conferences with 5 presented papers. Main research objects of the published papers are: budget, gender equality, gender inequalities, gender budgeting, gender sensitive budget analysis.

Josip Cičak, Mecon, is assistant at the Department of Accounting Faculty of Economics, University of Rijeka. He is a postgraduate (doctoral) student at Faculty of Economics, University of Rijeka. He is engaged in seminars and practice sessions on several courses: Accounting, Financial Accounting 1, Financial Accounting 2. He is certificated bankruptcy manager registered at Commercial Court in Rijeka, which gives him opportunity to work as forensic accountant. 


\section{References}

Anderson, P. M., \& Levine, P. B. (1999). Childcare and mothers' employment decisions (Working Paper 7058). Cambridge: National Bureau of Economic Research. Retrieved 1. 10. 2014, from http://citeseerx.ist.psu.edu/viewdoc/dow nload?doi=10.1.1.160.2377\&rep=rep1\&type=pdf

Baker, M., Gruber, J., \& Milligan, K. (2005). Universal Childcare, Maternal Labour Supply and Family Well Being (Working Paper 11832). Cambridge: National Bureau of Economic Research. Retrieved 1. 9. 2014, from http://www.nber. org/papers/w11832.pdf

Budlender, D. (2009). Ten-Country Overview Report Integrating gender responsive budgeting into the aid effectiveness agenda. New York: UNIFEM. Retrieved 3. 12. 2014, from http://www.gender-budgets.org/uploads/files/Ten-country overview report Eng\%5B1\%5D.pdf

Budlender, D., Sharp, R., \& Allen, K. (1998). How to do gender-sensitive budget analysis: Contemporary research and practice. London: Commonwealth Secretariat.

COE. (2005). Gender Budgeting: Final report of the Group of specialists on gender budgeting (EG-S-GB). Council of Europe: Strasbourg. Retrieved 21. 5. 2012, from http://www.coe.int/t/dghl/standardsetting/equality/03themes/gendermainstreaming/EG-S-GB(2004)RAPFIN_en.pdf

Combaz, E. (2013). Positive Impact of Gender Responsive Budgeting (GSDRC Helpdesk Research Report 977). Birmingham: University of Birmingham. Retrieved 21. 5. 2014, from http://gsdrc.org/docs/open/HDQ977.pdf

Connelly, R. (1992). The Effect of Childcare Costs on Married Women's Labor Force Participation. Review of Economics and Statistics, 74(1), 83-90. DOI: $10.2307 / 2109545$

De Henau, J., Meulders, D., \& O'Dorchai, S. (2010). Maybe Baby: Comparing Partnered Women's Employment and Child Policies in the EU-15. Feminist Economics, 16(1), 43-77. DOI: 10.1080/13545700903382703

Del Boca, \& D., Vuri, D. (2006). The Mismatch between Employment and Childcare in Italy: the Impact of Rationing. Centre for Household Income, Labour and Demographic Economics. Retrieved 15. 11. 2014, from http://dse.univr.it/ espe/documents/Papers/F/1/F1_4dv.pdf

EACEA. (2014). Ključni podaci o predškolskom odgoju i obrazovanju u Europi. Report from Eurydice and Eurostat. Luxembourg. Retrieved 10. 12. 2015, from http://eacea.ec.europa.eu/education/Eurydice/documents/key_data_ series/166HR.pdf

EC. (2013a). Barcelona objectives. European Commission. Retrieved 1. 7. 2015, from http://ec.europa.eu/justice/gender-equality/files/documents/130531 barcelona_en.pdf

EC. (2013b). Report on Progress on equality between women and men in 2012. European Commission. Retrieved 1. 9. 2013, from http://ec.europa.eu/justice/ gender-equality/files/swd_2013_171_en.pdf

Elson, D. (1999). Gender Budget Initiatives. London: Commonwealth Secretariat. Retrieved 20. 4. 2013, from http://www.undp.mn/publications/GenderBudgets/ Budgets\%20CD\%20section\%203/3.1\%20gender\%20neutral\%20gender\%20 blind.pdf 
Elson, D. (2002). Gender Responsive Budget Initiatives: Key Dimensions and Practical Examples. Paper from a High Level International Conference Strengthening Economic and Financial Governance through Responsive Budgeting, Brussels, 16-18 October 2001 (pp. 15-29). New York: UNIFEM.

Elson, D., \& Sharp, R. (2010). Gender-responsive budgeting and women's poverty. In S. Chant (ed.), International Handbook of Gender and Poverty: Concepts, Research, Policy (pp. 522-527). Cheltenham: Edward Elgar Publishing Ltd. Retrieved 1. 10. 2014, from https://books.google.hr/books?id=Q7Ep1pItVIAC\&P rintsec=frontcover $\# v=$ onepage\&q\&f=false

Galić, B. (2009). Društvena uvjetovanost rodne diskriminacije. In Rodna ravnopravnost i diskriminacija u Hrvatskoj, Proceedings (pp. 9-27). Zagreb: Biblioteka Ona.

Galizzi, G. (2010). The Formulation of Gender Sensitive Budgets: Integrating Gender into the Balanced Scorecard. Economia Aziendale, 1(3), 335-343.

Gelo, J., Smolić, Š., \& Strmota, M. (2010). Sociodemografske odrednice zaposlenosti žena u Hrvatskoj. Društvena istraživanja 20(1), 69-88.

Gornick, J., Meyers, M., \& Ross, K. (1996). Supporting the Employment of Mothers: Policy Variation Across Fourteen Welfare States (Sociology Paper 1). Retrieved 1. 10. 2014, from http://surface.syr.edu/cgi/viewcontent. cgi?article $=1000 \&$ context $=$ soc

Gornick, J., Meyers, M., \& Ross, K. (1998). Public Policies and the Employment of Mothers: A Cross-National Study. Social Science Quarterly 79(1), 35-54.

Government of India. (2007). Gender Budgeting Handbook for Government of India Ministries and Departments. Government of India: Ministry of Women and Child Development. Retrieved 13. 1. 2014, from http://wcd.nic.in/gbhb/ Link\%20hand\%20pdf/Gender\%20Budgeting\%20Hand\%20Book.pdf

Gustafsson, S., \& Stafford, F. (1992). Childcare subsidies and Labour supply in Sweden. Journal of Human Resources 27(1), 204-229. DOI: 10.2307/145917

Hauke, J., \& Kossowski, T. (2011). Comparison of values of Pearson's and Spearman's correlation coefficients on the same sets of data. Quaestiones geographicae 30(2), 87-93.

Hofbauer, H. (2003). Gender and Budgets - Overview Report. Institute of Development Studies. Retrieved 10. 12. 2012, from http://www.genderbudgets.org/index.php?option=com joomdoc\&view=documents\&path=suggest ed-readings/cutting-edge-pack-on-gender-and-budgets\&ltemid=587

Klasen, S., \& Lamanna, F. (2009). The impact of Gender Inequality in Education and Employment on Economic Growth: New Evidence for a Panel of Countries. Feminist Economics 15(3), 91-132.

DOI: $10.1080 / 13545700902893106$

Klatzer, E., Schratzenstaller, M., Buchinger, B., \& Schaffer, N. (2010). Gender Budgeting in the Constitution - A look at Formal and Real Conditions in Austria. Internationale Politik und Gesellschaft, 2, 48-64. Retrieved 21. 10. 2012, from http://library.fes.de/pdf-files/ipg/ipg-2010-2/05_a buchinger_us.pdf

Klatzer, E., \& Stiegler, B. (2011). Gender Budgeting - An Equality Policy Strategy. Friedrich Ebert Stiftung, (12).

Kreynfeld, M., \& Hank, K. (1999). The Availability of Childcare and Mother's Employment in West Germany (DIW Discussion Paper No.191). Berlin. Retrieved 1. 10. 2014, from https://ideas.repec.org/p/diw/diwwpp/dp191.html 
Krogstrup, S., \& Wälti, S. (2007). Women and Budget Deficits. Genova: Graduate Institute of International Studies. Retrieved 1. 8. 2014, from http://repec. graduateinstitute.ch/pdfs/Working_papers/HEIWP13-2007.pdf

Matković, T. (2008). Tko što radi? Dob i rod kao odrednice položaja na tržištu rada. Revija za socijalnu politiku 15(3), 479-502. DOI: 10.3935/rsp.v15i3.802

Mikucka, M. (2008). Variation in Women's Employment Across European Countries - The Impact of Childcare Policy Solutions. International Journal of Sociology 8(1), 12-37. DOI: 10.2753/IJS0020-7659380101

Mills, M. et al. (2014). Use of childcare in the EU Member States and progress Towards Barcelona target. Brussels: European Commission. Retrieved 10. 7. 2014, from http://www.cite.gov.pt/pt/destaques/complementosDestas/140502 gender_equality_workforce_ssr1_en.pdf

Misra, J., Budig, M., \& Boeckmann, I. (2010). Work-family policies and the effects of children on women's employment hours and wages. Community, Work \& Family 14(2), 139-157. DOI: 10.1080/13668803.2011.571396

Murphy, S. (2009). Investing in Girl's Education. An Opportunity for Corporate Leadership. Cambridge, MA: Corporate Social Responsability Initiative: Harvard Kennedy School. Retrieved 10. 7. 2014, from http://www.hks.harvard. edu/m-rcbg/CSRI/publications/report_40_investing_in_girls.pdf

Nallari, R., \& Griffith, B. (2011). Gender and Macroeconomic Policy. Directions in Development (139-151). Washington: World Bank Institute. Retrieved 1. 10. 2014, from https://openknowledge.worldbank.org/bitstream/handle/10986/225 6/589960PUB0ID171UBLIC109780821374344.pdf?sequence $=1$

Nordic Council of Ministers. (2006). Gender Budgeting-Integration of a gender perspective into the budgetary process - Country reports. Copenhagen: TemaNord. Retrieved: 20. 3. 2014, from http://www.gender-budgets.org/ index.php?option=com joomdoc\&view=documents\&path=resources/by-regioncountry/europe-cee-and-cis-documents/gender-budgeting-integration-of-agender-perspective-in-the-budgetary-process\&ltemid=542

OECD. (2012). Closing the Gender Gap: Act Now. OECD. Retrieved 1. 8. 2014, from http://www.oecd.org/gender/Executive\%20Summary.pdf

Powell, L. (1997). The Impact of Childcare Costs on Labour Supply of Married Mothers: Evidence from Canada. Canadian Journal of Economics 30(3), 577-594. DOI: http://dx.doi.org/10.2307/136234

Prenner, P. et.al. (2007). Gender Budgeting in Practice. Plzeň: Vydavatelství a nakladatelství Aleš Čeněk, s.r.o. Retrieved 7. 8. 2013, from http://www. vlada.cz/assets/ppov/rada-pro-rovne-prilezitosti/oddeleni/dokumenty/GenderBudgeting-2007.pdf

Ratsan, Y. (2008). Towards Gender Responsive Budgeting: Rising to the Challenge of Achieving Gender Equality. Ottawa: The Standing Committee on the status of Women. Retrieved 1. 7. 2014, from http://ywcacanada.ca/data/research docs/00000127.pdf

Schratzenstaller, M. (2008). Gender Budgeting in Austria. DICE, 6(2), 44-51. IFO Institute for Economic Research at the University of Munich.

Seguino, S., \& Floro, M.S. (2003). Does Gender Have Any Effect on Aggregate Saving? An Empirical Analysis. International Review of Applied Economics, 17(2), 1211-1230. DOI: 10.1080/0269217032000064026

Sikirić, A. M., \& Vašiček, D. (2013). Perspektive uvođenja rodnog proračuna u tranzicijskim zemljama. In E. Peštović (Ed.), Uloga računovodstvene profesije u realizaciji poslovnih ciljeva, Proceedings (pp. 351-367). Sarajevo: DES. 
Sikirić, A. M. (2013). Access to Gender Sensitive Budgeting - Some Tools and Methods. Economic Research, 26(Sup2), 193-208.

Spansenoska, I., \& Fetahu-Vehapi, M. (2011). Determinants of Female Employment Rate in the European Union. Chinese Business Review, 10(11), 1076-1090.

Stier, H., Lewin-Epstein, N., \& Braune, M. (2001). Welfare Regimes, FamilySupportive Policies, and Women's Employment along the Life-Course Source. The American Journal of Sociology 106(6), 1731-1760. DOI: 10.1086/321302

Swamy, A., Knack, S., Young, L., \& Azfar, O. (2001), Gender and Corruption. Journal of Development Economics, 64(1), 25-55.

DOI: 10.1016/S0304-3878(00)00123-1

Swiebel, J. (1999). Unpaid Work and Policy-Making Towards a Broader Perspective of Work and Employment. New York: United Nations Department of Economic and Social Affairs. Retrieved 1. 12. 2014, from http://www.un.org/esa/desa/ papers/1999/esa99dp4.pdf

UN Women. (2012). Evaluation of UN Women's Work on Gender Responsive Budgeting in India. New Delhi: United Nations Entity for Gender Equality and the Empowerment of Women. Retrieved 20. 3. 2014, from http://www.fsg. org/Portals/0/Uploads/Documents/PDF/Evaluation_of_UN_Womens_Work on_Gender_Responsive\%20Budgeting_in_India.pdF?cpgn=WP\%20DL\%20-\%20 UN\%20Women\%20India\%20Budgeting\%20Evaluation

Viitanen, T. (2005). Costs of Childcare and Female Employment in England. Labour, 19(S1), 149-170. DOI: 10.1111/j.1467-9914.2005.00325.x

Ward, J., Lee, B., Baptist, S., \& Jackson, H. (2010). Gender Equality and Economic Growth. London: Chatham House. Retrieved 1. 8. 2014, from https://www. chathamhouse.org/sites/files/chathamhouse/public/Research/Energy,\%20 Environment\%20and\%20Development/0910gender.pdf

Wehner, J., \& Byanyima, W. (2004). Parliament, the Budget and Gender. France: SADAG S.A. Retrieved 1. 12. 2013, from http://www.ipu.org/PDF/publications/ budget_en.pdf

Wrochlich, K. (2004). Childcare Costs and Mothers' Labor Supply. An Empirical Analysis for Germany (DIW Discussion Paper No. 412). German Institute for Economic Research. Retrieved 1. 10. 2014, from https://ideas.repec.org/p/diw/ diwwpp/dp412.html 
POVZETEK

\subsection{Pregledni znanstveni članek}

\section{Javna poraba na področju otroškega varstva kot kazalnik upoštevanja različnosti spolov v proračunu}

Ženske so danes izredno velik delovni potencial, vendar njihov status na trgu dela ne odraža njihove izobrazbe. Na trgu dela je še vedno prisotna spolna neenakost, ki se kaže v nižji aktivnosti ženske delovne sile, nižji stopnji zaposlenosti in nižjih dohodkih žensk v primerjavi z moškimi. Vse to je deloma posledica družbeno oblikovane vloge ženske kot matere in gospodinje, zaradi česar so ženske, ki so obremenjene z gospodinjskimi opravili in s skrbjo za otroke, na trgu dela v slabšem položaju kot moški. Zaradi obveznosti v okviru neplačanega dela imajo ženske premalo časa za vključitev na trg dela in za zaposlitev za polni delovni čas. Nezmožnost zaposlitve za polni delovni čas pa vodi v finančno odvisnost od moškega ter posledično do spolne neenakosti tudi na drugih družbenih področjih.

Glede na to, da mora vlada spodbujati enakost vseh prebivalcev, prerazporejati sredstva po različnih področjih ter se truditi v enaki meri zadovoljiti potrebe vseh prebivalcev, tako moških kot žensk, se v zadnjih dvajsetih letih vse bolj poudarja, da morajo vlada in preostali nosilci oblasti pred sprejetjem vsake odločitve o zbiranju in porabi javnih financ, poleg drugega, ugotoviti, kakšne učinke bo odločitev imela na ženske in kakšne na moške. Proračun, s katerim se poskuša odpraviti obstoječa neenakost spolov, se v teoriji imenuje "proračun, občutljiv na spol« oziroma »spolni proračun«.

Tak proračun teži k zadovoljitvi potreb tako moških kot žensk s ciljem večje enakosti spolov. Enakost spolov je mogoča le, če bodo ženske finančno neodvisne oziroma zaposlene, zaposlile pa se bodo takrat, ko bodo lahko uskladile svoje profesionalne in družinske obveznosti. Za zadovoljitev potreb žensk je nujno, da se iz proračuna financirajo ukrepi, ki bodo omogočili usklajevanje profesionalnega in družinskega življenja. Eden takšnih ukrepov je tudi storitev predšolske vzgoje in izobraževanja, ki ženski omogoča, da se malce »osvobodi« od celodnevnega ukvarjanja z otroki. Zato so lahko javni izdatki za storitve predšolske vzgoje in izobraževanja indikator proračuna, občutljivega na spol.

Raziskava temelji na predpostavki, da storitve predšolske vzgoje in izobraževanja z zmanjšanjem obsega neplačanega dela žensk pripomorejo k večji enakosti spolov na področju izrabe časa, s tem pa se ustvari temeljna predpostavka za intenzivnejše vključevanje žensk na trg kot osnovni pogoj za večjo enakost spolov v družbi. Vendar lahko predpostavljamo, da obstaja korelacija tudi $v$ nasprotni smeri; ženske se po končanem porodniškem dopustu želijo vrniti na trg dela in težijo k zmanjšanju neplačanega dela, kar 
povečuje povpraševanje po storitvah predšolske vzgoje in izobraževanja, posledica večjega povpraševanja pa so večja ponudba in višji javni izdatki za storitve predšolske vzgoje in izobraževanja.

Glede na to, da ni povsem preprosto določiti povezave med storitvami predšolske vzgoje in izobraževanja ter zaposlovanjem mater, je z izračunom Pearsonovega koeficienta mogoče določiti stopnjo povezanosti javnih izdatkov, dostopnosti storitev predšolske vzgoje in izobraževanja, enakosti spolov na področju izrabe časa in zaposlenosti mater. Cilj je raziskati, ali višji javni izdatki za storitve predšolske vzgoje in izobraževanja in večja dostopnost le-teh z zmanjšanjem obsega neplačanega dela žensk povečujejo enakost med spoloma na področju izrabe časa in zaposlenost žensk z otroki, mlajšimi od 6 let, in obratno.

Dobljeni koeficienti korelacije potrjujejo povezavo med višino javnih izdatkov za storitve predšolske vzgoje in izobraževanja in njihovo dostopnostjo. Drugače povedano, nujno je uporabiti javna sredstva in z njihovo pomočjo storitve predšolske vzgoje in izobraževanja približati večjemu številu prebivalcev ter tako zmanjšati obseg neplačanega dela v gospodinjstvu in povečati enakost med spoloma na področju izrabe časa. Zmanjšanje obsega neplačanega dela in večja enakost spolov glede časa omogočata ženskam lažje usklajevanje družinskih in profesionalnih obveznosti ter pomagata k intenzivnejši vrnitvi žensk na trg dela, kar vsekakor pozitivno vpliva na enakost spolov na trgu dela. Največja povezanost enakosti spolov na področju izrabe časa in zaposlovanja žensk z otroki, mlajšimi od 6 let, je zabeležena s spremenljivko, ki se nanaša na delež zaposlenosti žensk z enim otrokom, mlajšim od 6 let, v stopnji zaposlenosti žensk brez otrok, kar kaže na to, da storitve predšolske vzgoje in izobraževanja k vrnitvi na trg dela v največji meri pripomorejo ženskam z enim otrokom, medtem ko so ženske z dvema otrokoma manj zastopane, ob predpostavki, da slednje kljub storitvam predšolske vzgoje in izobraževanja težje usklajujejo družinske in profesionalne obveznosti. Trije ali več otrok, mlajših od 6 let, zagotovo predstavlja dodatno težavo pri usklajevanju profesionalnih in družinskih obveznosti, vendar je koeficient korelacije nekoliko višji kot pri ženskah z dvema otrokoma. To pomeni, da povečanje dostopnosti storitev predšolske vzgoje in izobraževanja povečuje zaposlenost žensk s tremi ali več otroki, ne pa žensk z dvema otrokoma. To si lahko razlagamo tudi tako, da bi se, če storitve predšolske vzgoje in izobraževanja ne bi bile dostopne, za vrnitev na trg dela odločilo manj žensk s tremi ali več otroki kot žensk, ki imajo dva otroka. Torej zagotavljanje storitev predšolske vzgoje in izobraževanja v večji meri povečuje zaposlovanje žensk s tremi ali več otroki kot pa zaposlovanje žensk z dvema otrokoma. 